\title{
Preliminary Stand Table for Average Dominant Trees of Jati Plus Perhutani in Saradan, Madiun, and Ngawi Forest Districs
}

\author{
Rissa Rahmadwiati*, Ronggo Sadono, Nunuk Supriyatno
}

\begin{abstract}
Department of Forest Management, Faculty of Forestry, Gadjah Mada University, Yogyakarta, Jl. Agro No. 1, Bulaksumur, Yogyakarta, Indonesia 55281
\end{abstract}

Received September 16, 2015/Accepted 29 January, 2016

\begin{abstract}
In order to realize sustainable teak forest management, the strategic plan of forest management is highly needed to establish the growth characteristics model of jati plus perhutani (JPP). The most thing which cannot be ignored to estimate the growth and yield of teak is quantification of site quality differentiation. The objective of this study were to arrange and predict the properly yielded table of the average dominant trees of JPP in the forest management unit of Saradan, Madiun, and Ngawi. The trees sampling had been selected for the age of 6 to 12 years from the best compartment areas in JPP. Growth model and JPP's yield stands were predicted using growth parameters such as diameter (dbh), total height, clear bole height, volume, and growing space. Each parameter was analyzed using SPSS 20 statistical software to determine the best growth model that will then be used to predict the stand table parameters values. The equation was selected from the highest $R^{2}$ value or the value which is approaching to 1 , with low standard error estimation (SEE). The result showed that best equation model to estimate the growth from tree parameters on medium site of JPP were dominated by S model and the best model for bole height was growth model. The data were taken from an initial observation as a preliminary study, further research is expected to enhance the results of current research to obtain the stand table which can be applied in the future.
\end{abstract}

Keywords: Jati Plus Perhutani, model, growth, site quality

*Correspondence author, email: icha.rissa01@gmail.com,ph.: +62-89638394145

\section{Introduction}

In order to realize sustainable teak forest management, especially for Jati Plus Perhutani (JPP), the strategic plan of good forest management is necessary to determine the growth characteristics of JPP. According to Davis and Johnson (1987), stand growth is the change in size of the selected properties stand (stand dimensions) that occurs during a particular period. Information about tree growth and yield is highly needed in the forest management plan. Therefore, the growth and the yield of JPP estimation model are required to be established as a reference for forest management plans.

Nowadays, wood becomes material that is frequently utilized for a specific purpose. Teak wood (Tectona grandis) is one of the most widely used timbers. This wood is found to be valuable because of its resistance and dimensional stability as well as aesthetic value (Miranda et al. 2011) Further, it is also resistant toward termites and fungus (Lacret et al. 2012) what makes it used widely in the wood industry. Teak wood is classified in the class of II in term of durability and strength and commonly used as construction materials or building materials, energy, and composites raw materials industry. Apart from having high quality, teak wood also has a decorative and artistic value with circular patterns which is clearly observable. Impression of touch, texture and distinctive smell make it seem to be luxurious. In terms of wood processing, this wood is easy to work with, either by machine or by hands. This wood can be well polished and lacquered (Martawijaya et al. 1989), what makes it widely utilized in furniture and handicraft industry.

Perum Perhutani as one of the state owned enterprises (BUMN) engaged in the management of forests in Java Island still relies on this kind of wood as the main commodity. Demand of this wood in both domestic and export markets are growing while the ability to meet market demand has been decreasing (Siswamartana \& Wibowo 2005). In addition, supply shortage was also as the result of degradation of forest stands. Degradation on the areas managed by Perum Perhutani was as the impact of several factors such as illegal logging, forest fires and forest disturbance (Rohman et al. 2014). Destruction of forests has been largely led to their conventional teak stands dominated by younger age classes (age classes of I and II). The composition of the forest class brings problems related to the number of forest stand, which unready to be harvested (Rohman 2008). By referring to this, Perum Perhutani is 
encouraged to develop innovations in teak breeding such as JPP which is relatively shorter in cycle but having similar quality.

JPP is a superior product of Perhutani obtained from tree restoration programs or silvi-culture since 1998 in order to accelerate utilization of the results of tree restoration for constructing plants. JPP was developed in 2 ways, vegetative propagation (cuttings and tissue culture) and generative propagation where JPP seeds are taken from clonal seed orchad (KBK). PHT I and PHT II are the 2 clones best selected due to its superiority and stablity, generated through Perum Perhutani tree restoration program. Moreover, these have also gained legal permit for perlindungan varietas tanaman (PVT) from Plant Variety Protection Center Department of Agriculture in 2009. JPP is adaptable in various sites as it is taken from a very strict selection process (Sadono 2014). JPP grows faster (with productivity 2-3 times faster than ordinary teak wood), and grows well in both lean and arable land. JPP is straight, has a high degree of uniformity, has straight and cylindrical trunks, with a rapidly recycling plant of 20 years, has a good quality of wood, which is resistant to disease and has a high economic value (Perum Perhutani 2011).

Plantation including to ones owned by Perum Perhutani were generally built to be utilized as raw material for constructing ships, making outdoor equipment, furniture, and for general carpentry (Sadono 2014a). Forest sustainability has been getting more and more important as the demand for wood keeps increasing, meanwhile the sustainability of raw materials both quantity and quality has been decreasing. Without any serious acts of all related parties in term of preventing degradation of forest resources, the potential of tropical forests in Indonesia is about to decline sharply exceeding the threshold of natural regeneration ability. Stand growth or it is often referred as increment is very important in forest management. The yield sustainability will be achieved when the results of the harvest does not exceed the ability of stand to grow (increment).

Growth and yield of a plant species for exampple teak wood, is very important to constuct a model of growth and the yield (growth and yield models). The purpose of growth and yield models are for inventories renewal, structure and stand productivity estimation, silvi-cultural systems evaluation, and as a basic reference for policy development and forest management planning (Burkhart 2012). To determine the growth of JPP, Perhutani currently uses a reference table for teak stands growth according to Wolf von Wolfing table $(\mathrm{WvW})$. But in its development, several studies have shown differences in JPP growth according WvW Table. Forest department unit (KPH) Kendal has made permanent sample plots (PUP) to observe the growth of JPP (diameter, height and volume) which is held annually. The results of the initial measurement PUP on JPP plants in 2011 shows that increment of JPP plants for all age classes and bonita are under the value in Table WvW (Perum Perhutani 2011). According to Sadono (2014b) JPP diameter and height of trees grow faster at the age of 5 years. From the results of the evaluation conducted in KPH Pemalang, it shows that the plants at the age of 5 years have an average height of $17.8 \mathrm{~m}$ with a diameter of $18 \mathrm{~cm}$ to which it exceeds the growth of stands according to the Table $\mathrm{WvW}$ in Bonita VI (Siswamartana \& Wibowo 2005). In fact, Basri and Wahyudi (2013) stated that, at the same age, trunk diameter of JPP is nearly 2 times larger than the conventional teak wood. The differences in JPP growth with WvW Table can obstruct forest management if $\mathrm{WvW}$ Tables are still being used for reference and will affect the company efficiency. Therefore, it is necessary to study the growth and yield modeling of JPP stands which are expected to be able to be used as a reference in forest management activities that can optimized JPP wood production.

Sadono (2015) determined 3 different classes (good, medium, and poor) of site quality of JPP located in the area of KPH Madiun, Ngawi, and Saradan. To find out the growth of JPP and to find out which sites best to grow well JPP around the area of forest planning section (SPH) Madiun, this study will discuss further the issue by designing table stand of JPP based on the average dominant trees.

\section{Methods}

Description of study site The research was conducted using the measurement data in 2013 and 2014 in JPP compartment of the area of SPH Madiun which include KPH Saradan, KPH Madiun, and KPH Ngawi, Perhutani East Java Regional Division. Samples of plants from JPP permanent compartments were determined by the selection of 30 dominant JPP trees which have good quality and resistance, which include variations in age ranged 6-12 years, derived from the clonal seed orchard and site quality. The number above is determined by considering the requirements of the normal distribution form. This study only measured the dominant trees as JPP is basically a superior product that has excellent productivity, it can be seen from the height and diameter growth. Thus, it is assumed that JPP stand will produce the products with the same conditions. The optimum productivity and quality will be visible on the dominant tree. JPP trees were not measured by using sample plot with particular size, we only measured in one time to get the reference trees. To estimate the growth and yield of JPP, measurements of diameter and height performed on 30 samples obtained from the JPP dominant tree compartments for each age 6-12 years. The estimation of standing tree volume was determined by bole height tree and diameter at breast height (dbh) which were analyzed by Smallian formula.

The dominant tree can be used as a need indicator of actual growing space. This information can be used to determine the estimation of the growing space (Sadono et al. 2014). Tree growth is influenced by the growing space to which this space is strongly correlated with physiological process of tree in growing wood (Baldwin et al. 2000; Perez $\&$ Kanninen 2005). Besides, the selected tree is the dominant ones, referring Uriarte et al. (2004) the dominant tree has characteristics that can be used to grow and survive. The characteristics which is more physiological becomes determining factors for growth and life sustainability of the tree (Sadono 2014b). The selection of compartments was conducted by determining 3 specific compartments in each class of age (6-12 year) for every KPH. Sample selection was conducted through purposive sampling by selecting tree 
for each block based on criteria considered to represent the forest condition in the site.

Crown plays an important role in supporting productivity of the tree. Crown is a physiological process, which combined a number of solar energy, particularly in photosynthesis, respiration and transpiration. The formation of crown comes from the environmental factors and the existing supply in the forest. The shape of crown is determined by the characteristics of the branch (the angle and length of the main branch and branch ratio) (Sadono 2015).

According to Pretzsch (2009) crown is one of the morphological characteristics of tree which plays an important role that can be seen and measured. Growth of biomass per unit area is determined from the size of the tree and the hierarchical crown position within the canopy (Pretzsch \& Schutze 2005). While the size of the tree crown is associated with photosynthetic capacity to which it is an important parameter of the forest stand growth. Crown is also very relevant to measure the correlation among canopy size and trunk diameter, and tree density in the stand (Hemery et al. 2005). In this study, the growing space was predicted by measuring the crown projection area based on its crown diameter. Referring to the Foli et al. (2003) crown diameter can be measured from the 4 sides of its radius. To determine the growing space and crown projection in this study, crown diameter was measured within each of wind directions, (north, south, west, and east). Measurements were performed 2-3 times in order to get an accurate results (Laar \& Akca 1977; Sadono 2015).

Data analysis In the early stages of growth and the result of modeling forest stand, data were checked using descriptive analysis software, SPSS 20. Descriptive analysis distribution of the height average of the dominant trees of JPP was done by eliminating outliers. Results of data distribution showed that the data were distibuted in various ways to each class of age. According to Sadono (2015), the stand of JPP in SPH Madium has classified the dominant trees based on the result measurement of quality class of the site ranging from good to poor. Furthermore, analysis of regression and curve estimation were done by including the age variable and height average of dominant tree in each class to determine the growth model of each site quality class of JPP. The generated value of the analysis was used to describe the curve fit site based on the average height of dominant tree. Selection for the best model of growth and yield in each class of JPP were selected through an equation which has a high $\mathrm{R}^{2}$ value that is approaching the value of 1 , to which it has the smallest value of the standard error of the estimation. Linear regression analysis was used to process the data, the data-set being used were not the time series data ranged from 2013-2014 kept in the same compartments, instead, these were data collection of the year 2013 and 2014 which were conducted in different tree compartments.

To estimate growth space from each tree, the following equation was used (Pretzsch 2009) as shown as Equation [1].

$g s s=(10,000 / n)$

gss represents the growth space of trees. While $n$ is the quantity of dominant tree in the stand. To determine growth space of dominant tree in hectare of stand, the following equation is used as shown as Equation [2].

$n=(10,000 / g s s)$

Pretzsch (2009) stated that to determine the quantity of dominant tree $(n)$, the average spacing between each tree can be quantified through the following as shown as Equation [3]:

dist $=(1 / \sqrt{ } n) \times 107,46$

futhermore, to calculate area of crown projection, this following equation was used as shown as Equation [4].

$g s_{h}=c d^{2} \times(0,5 / \sqrt{ } 3)$

where $c d$ is crown diameter $(\mathrm{m})$. To calculate the individual quantity per hectare, quadrangle and hexagon pattern were calculated using this Equation [5] and Equation [6].

quadrangle $=10,000 \mathrm{~cd} \mathrm{~d}^{2}$

hexagon $=\left(10,000 / c d^{2}\right) \times 0.866$

Once the best model based on the criteria was found, the bole height as well as diameter at breast height can be estimated. To predict the growth parameters, the best equation model obtained through the regression analysis could be calculated by entering the significant independent variable. Those parameters are arranged in table stand. Of the measurement results which is obtained and identified, the parameters of growth was expected to be compiled by age, site quality and dominant height of JPP. Construction of table stand was used to describe the condition of JPP stands at SPH Madiun.

\section{Results and Discussion}

Teak wood is one of the most luxurious wood product. It is the most demanded wood in market. Teak wood is also recognized as wood with nice fiber and texture. Teak wood has good quality as it has a stable, strong, and durable characteristic. JPP as a superior teak wood should have a good performance that can be seen from the growth and yield. Knowing the growth of JPP by stand table is a kind of management planning.

In the process of planning for JPP plant development, any information about the potential, growth, and the site quality is needed. According to Sadono (2015), the choosen trees were classified according to the criteria of crown, quality class and total height of dominant trees which is in accordance with its site quality class namely good, medium and poor. Sadono (2015) shows the classification of JPP stands table site classes in SPH Madiun which is used to classify the quality of its site.

Such information can be provided in the form of a model or equation obtained through the consrtruction and measurements on the JPP plant. The result of curve estimation regression analysis shows that best equation model to estimate the growth of tree parameters such as dbh, bole height volume, and crown projection on the medium site of JPP are dominated by S model. While the best model for bole height is growth model. The medium site class of JPP in SPH Madiun tends to show a good growth having normal distribution of the total height, bole height, $\mathrm{dbh}$, and bole height volume. 


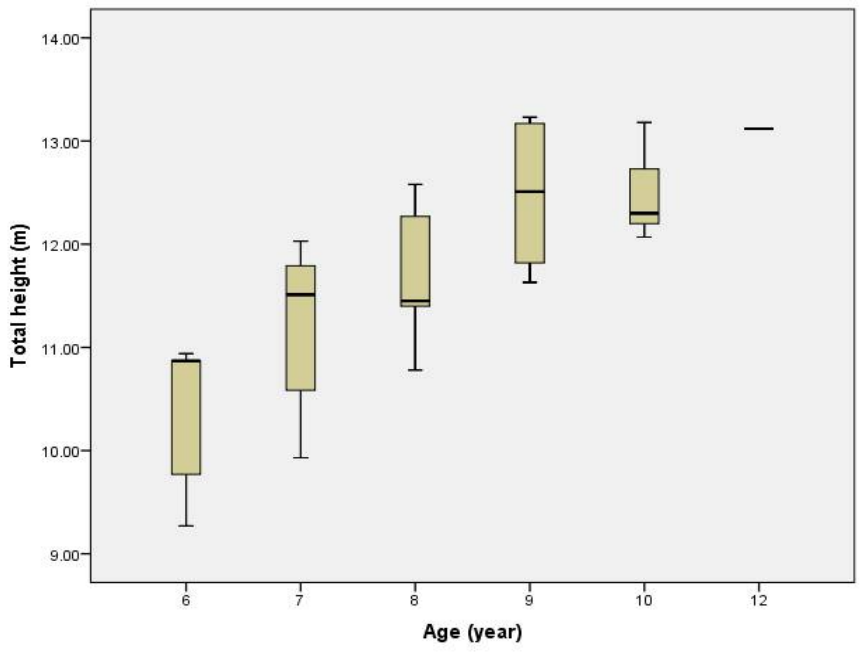

Figure 1 Distribution of total height in boxplot of medium site.

The stand table construction could be accelerated through further analysis of each variable. The equation result, in this case will then be used as predictive value in the stand variables. In addition, the determination on the upper limit of the good site class and lower limit in the poor site class cannot also be conducted (Sadono 2015). Therefore, this research is focused on the medium site class. According to Clutter et al. (1983) site quality can be measured using direct and indirect the method. Direct method with dominant tree is found to be the most efficient and widely used method. Due to the fact that this variables is strongly correlated with stand result and other factors, David (2014) argued that site quality is an important parameter to establish a management regime. By paying attention to this regime, the high productivity site will always provide a higher result than the low productivity site. Furthermore, the area of thinning will be determined in accordance with the quality of the site. Mistake in decision making in relation with thinning will affect the economic value of the stand yield. According to Sadono (2015), a graphic of JPP stands site quality class in Madiun, SPH is classified into 3 classes, namely good, medium and poor.

Results from a total height of the dominant tree in the form of box plots medium site for each age is presented in Figure 1. From the figure, it can be seen that all data related to the total height measurement results did not contain outliers values. It means that the data were distributed normally.

Bole height measurement results are processed using descriptive statistics and the box-plots towards age were made to determine the distribution of dominant tree bole height for each age. Results of the dominant tree bole height is presented in the form of box plots medium site used for each age (Figure 2). Of the figure, it can be see that all data of bole height in the result of measurement containing outlier values is just for the age of 8 years in the medium site class.

Diameter of breast height measurement results are processed using descriptive statistics and the box plots towards age were made to determine the distribution of dominant tree diameter for each age class. The dominant tree

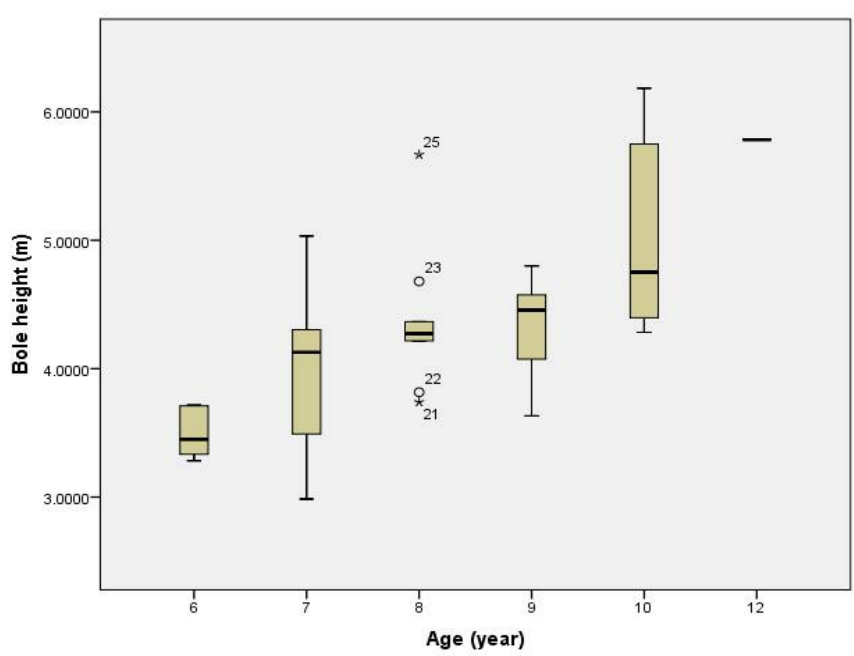

Figure 2 Distribution of bole height in boxplot of medium site.

trunk diameter distribution is presented in the form of box plots Medium site class used for each age (Figure 3). From the figure, this can be seen that all the data of diameter measurement results do not contain outliers values.

According to Davis and Johnson (1987), growth is defined as an increase in numbers and dimension in both diameter and tree height found in the stand. The vertical growth (height) is the primary growth, while the horizontal growth (diameter) is the secondary growth. The growth of forest stand is defined as a change in the size and characteristics of the selected stand (stand dimension) happening in the particular period of time, while result is the amount of stand dimension that can be harvested in the particular period of time. The difference between growth and result are located in the idea that biological production is for stand of economic growth and harvest for generating stand.

Forest management happens in the state of result sustainability. This is important if the result is linear with sustainable growth. It can be stated that the amount of obtainable maximum result in the forest within the period is a cumulative growth to the time given, while the amount of maximum result that can be sustainably harvested within the period is similar with the growth in the period (Davis \& Johnson 1987). The tree growth in the same areas, each of the trees has the different ability to adapt and has different morphology as well (Raharjo 2009). There is growth happening simultaneously of parts of the trees and can be measured by using various parameters such as diameter, height, crown wide, volume, and etc. This growth can be measured in the physical unit such as volume, basal area and weight. Besides, this can also be measured in the variables of interest (Davis \& Johnson 1987).

Growth is influenced by the growing site factors such as stand density, stand age characteristics, climatic factors (temperature, precipitation, wind speed and humidity), and soil factors (physical properties, chemical composition, and soil microbiology component). In addition the growth also influenced by the cropping pattern (Setyaningsih et al. 


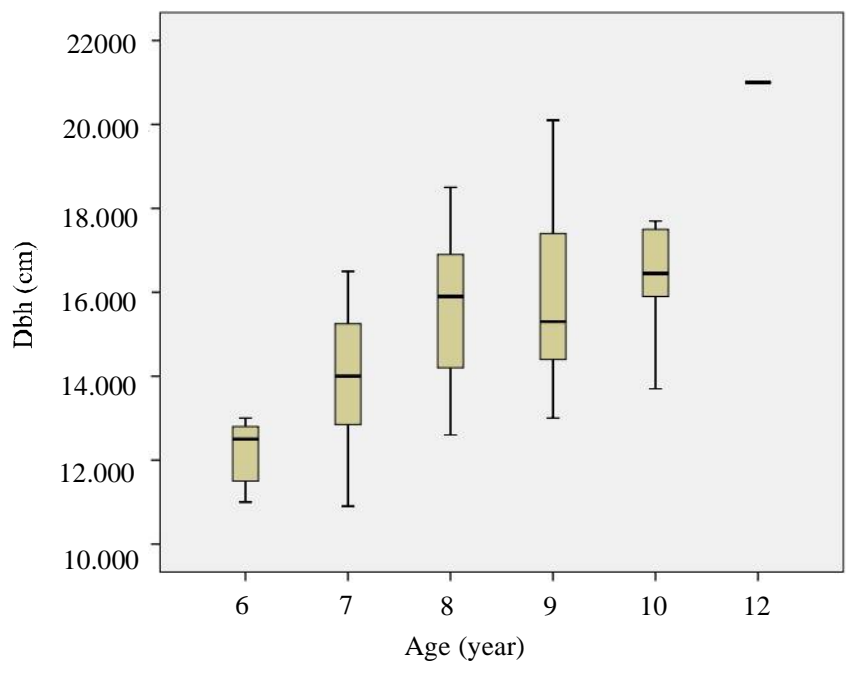

Figure 3 Distribution of diameter in breast height (dbh) in boxplot of medium site.

2009). Tree growth was also influenced by the growth space, where in teak plantations, it is necessary to control the competition between individuals in order to get light and space for the root system. Growth space is correlated with the physiological processes of each tree in producing wood (Baldwin et al. 2000; Perez \& Kanninen 2005). Diameter growth is influenced by factors that affecting photosynthesis. Diameter growth happens if the purpose of photosynthesis such as respiration, leaves replacement, roots, and height growth has been met. Height growth is influenced by difference of time length to establish foliage which is very sensitive to the quality of the site. There are at least 3 environmental factors and a genetic factor (internal) which affected height growth, namely mineral nutrient content of the soil, soil moisture, sunlight, and also genetic trait balance between the height and diameter growth (Davis \& Johnson 1987).

Volume measurement results were processed with descriptive statistics and the box-plots towards age were made to determine the distribution of dominant tree volume for each age class. The dominant tree volume distribution is presented in the form of box plots medium site class used for each age (Figure 5). From the figure, it can be seen that all volume data on the measurement results that contain outlier values only happened at the age of 6,9 , and 10 years in the medium site class.

The projection distribution of the dominant tree crown is presented in the form of box plots medium site class used for each age (Figure 5). From the figure, it can be observed that all data related to crown projection measurement results did not contain outliers values. The crown projection results were used to predict the growing space of JPP.

Sadono (2014b) stated that growing space of the dominant group could be used for optimum growing space estimation in each group. The number of trees in JPP areas were determined by the calculation of crown projection and crown diameter based on growing space. Based on the growing space requirement, there were 2 ways to determine the number of trees; square pattern and hexagonal pattern.

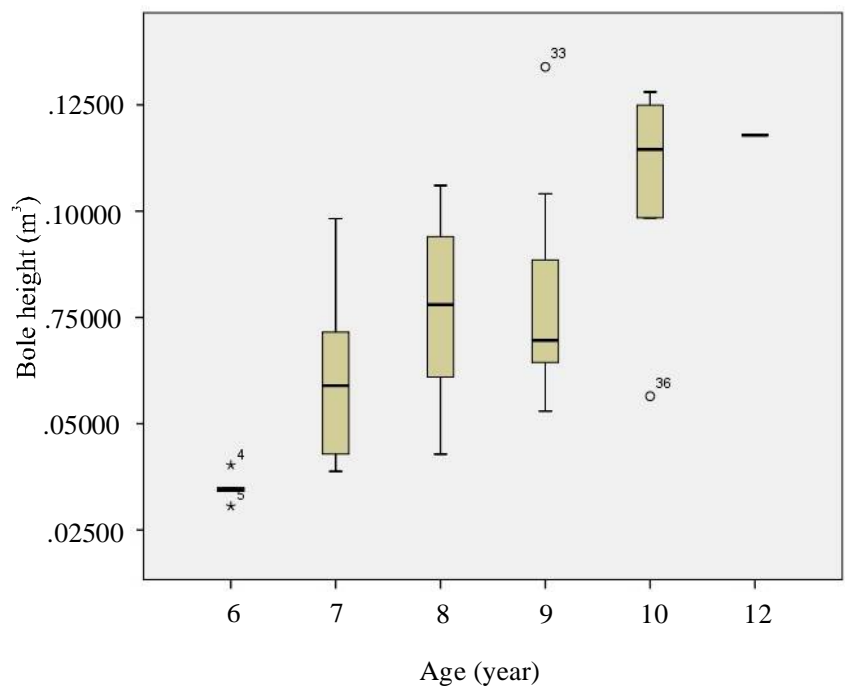

Figure 4 Distribution of tree volume in boxplot of medium site.

This study showed that hexagonal pattern was found to be the most effective one to be applied in JPP since land use in JPP area has been optimized especially for growing space.

Crown has an important role in the growth, as stated by Laar and Akca (2007) that the characteristics of the crown can be used to estimate the response of the growing space, thinning, fertilizing and soil moisture. As a result, 6 characteristics of the crown can be used to determine the growth model through estimating the gap between crown and another crown characteristics. According to Daniel et al. (1987) and Krishnapillay (2000), the crown area was positively correlated with root radius to take up nutrients from the soil. In addition, the area of the crown can positively support the process of photosynthesis.

Table 1 shows that the model chosen for each parameter in the medium site to estimate growth parameters were varied because selection criteria requires the highest $R^{2}$ value approaching 1 and the lowest SEE value approaching 0 . After being classified into site class, many age classes tend to accumulate in the medium site class. The construction of JPP stands table was further analyzed by the individual constituent variable. Each of these dominant variables such as height, growing space, bole height, diameter (dbh) and bole volume were analyzed to gain the equation, the results of the equation will then be used as a predictive value of each stand table variable.

In the process of constructing stands table, there are columns that had not been estimated perfectly. Table 2 is a stand table of the medium site class in SPH Madiun. In the medium site class for age 11 , this can not be predicted because the results that had been obtained from the field did not belong to those 2 classes. However, the values in the table should be equipped with an estimation. The columns were then enhanced by determining the value estimated by using the same equation with each parameter in every age. Through inserting age variable in the column that had not been filled, making the values in the column that had not been filled could be determined. For further research, collecting more 


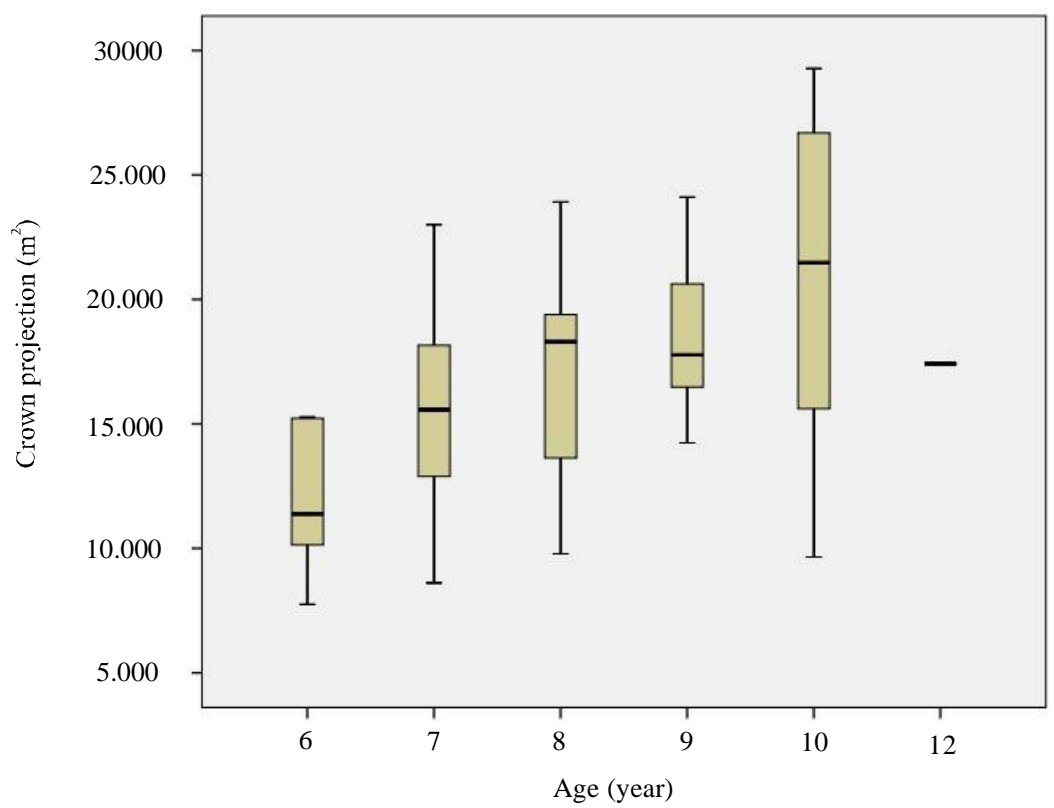

Figure 5 Distribution of crown projection in boxplot medium site.

Table 1 Best equation model to estimate growth from tree parameter on medium site

\begin{tabular}{lclccc}
\hline Parameter & Best model & \multicolumn{1}{c}{ Equation } & $R^{2}$ & SEE & Sig $(P$ value $<0.05)$ \\
\hline Bole height & Growth & $=\exp ^{\left(0.838+\left(0.075^{*} \mathrm{age}\right)\right)}$ & 0.428 & 0.124 & 0.000 \\
Diameter at breasth height & $\mathrm{S}$ & $=\exp ^{(3.3-(4.732 / \mathrm{age}))}$ & 0.422 & 0.123 & 0.000 \\
Bole height volume & $\mathrm{S}$ & $=\exp ^{(-0.925-(13.911 / \mathrm{age}))}$ & 0.532 & 0.289 & 0.000 \\
Crown projection & $\mathrm{S}$ & $=\exp ^{(3.532-(5.861 / \mathrm{age}))}$ & 0.780 & 0.098 & 0.020 \\
\hline
\end{tabular}

Table 2 Table of average dominant trees of JPP stand on medium site

\begin{tabular}{|c|c|c|c|c|c|c|c|c|c|}
\hline \multirow[t]{2}{*}{ Age } & \multicolumn{2}{|c|}{$\begin{array}{c}\text { Dominant height } \\
(\mathrm{m})\end{array}$} & \multirow{2}{*}{$\begin{array}{l}\text { Growth } \\
\text { space } \\
\left(\mathrm{m}^{2}\right)\end{array}$} & \multicolumn{2}{|c|}{$\begin{array}{c}\mathrm{N} \\
\text { (number of tree individu) }\end{array}$} & \multirow{2}{*}{$\begin{array}{l}\text { Bole height } \\
\text { average } \\
\text { (m) }\end{array}$} & \multirow{2}{*}{$\begin{array}{l}\text { Dominant } \\
\text { height } \\
\text { average } \\
\text { (m) }\end{array}$} & \multirow{2}{*}{$\begin{array}{c}\text { Diameter } \\
\text { average } \\
(\mathrm{cm})\end{array}$} & \multirow{2}{*}{$\begin{array}{c}\text { Bole height } \\
\text { volume } \\
\text { average }\left(\mathrm{m}^{3}\right)\end{array}$} \\
\hline & lower & upper & & Square & Hexagonal & & & & \\
\hline 6 & 8.83 & 11.25 & 12.87 & 610 & 704 & 3.63 & 10.41 & 12.32 & 0.03903 \\
\hline 7 & 9.84 & 12.09 & 14.80 & 531 & 613 & 3.91 & 11.16 & 13.79 & 0.05435 \\
\hline 8 & 10.67 & 12.77 & 16.43 & 478 & 552 & 4.21 & 11.76 & 15.01 & 0.06968 \\
\hline 9 & 11.36 & 13.31 & 17.83 & 441 & 509 & 4.54 & 12.24 & 16.03 & 0.08453 \\
\hline 10 & 11.95 & 13.77 & 19.03 & 413 & 477 & 4.89 & 12.64 & 16.89 & 0.09866 \\
\hline 11 & 12.45 & 14.15 & 20.07 & 391 & 452 & 5.27 & 12.98 & 17.62 & 0.11195 \\
\hline 12 & 12.88 & 14.48 & 20.98 & 374 & 432 & 5.69 & 13.27 & 18.28 & 0.12440 \\
\hline
\end{tabular}

data sample are necessary, so that each age class from each site can be represented.

\section{Conclusion}

Best equation model to estimate the growth on medium site of JPP from tree parameters such as dbh, bole height volume, and crown projection were dominated by S model. Meanwhile, best equation for bole height is growth. The data were taken from an initial observation as a preliminary research, further research is expected to further enhance results of current research in order to obtain the results of stand table which can be applied in the future. 


\section{Acknowledgments}

We are grateful to Gadjah Mada University for the financial support, and Perum Perhutani East Java Region Division for giving permit. Special thanks for management and staffs of Madiun, Saradan, and Ngawi Forest District for logistical support, use of facilities and kind help. We are also thankful for the measurement team and anyone who support this research and manuscript as well as anonymous reviewers for constructive comments on this manuscript.

\section{References}

Baldwin Jr VC, Peterson KD, Clark III A, Ferguson RB, Strub MR, Bower DR 2000. The effects of spacing and thinning on stand and tree characteristics of 38-year-old loblolly pine. Forest Ecology and Management 137(1):91-102. http://dx.doi.org/10.1016/S03781127(99)00340-0.

Basri, Wahyudi. 2013. Nature of teak plus perhutani in different age and relation to nature and drying quality. Jurnal Penelitian Hasil Hutan 31(2):93-102.

Burkhart HE, Tome M. 2012. Modeling Forest Trees and Stands. New York: Springer.

Clutter JL, Fortson JC, Pienaar LV, Brister GH, Bailey RL. 1983. Timber Management: A Quantitative Approach. New York: Wiley.

Daniel TW, Helms JA, Baker FS. 1987. Prinsip-prinsip Silvikultur (translated version). Yogyakarta: Gadjah Mada University Press.

David HC, Netto SP, Arce JE, Corte APD, Filho AM, Behling A. 2015. Updating of dominant height growth modeling and site of Pinus taeda L. in southern Brazil. Australian Journal of Basic and Applied Sciences 9(2):115-125.

Davis LS, Johnson KN. 1987. Forest Management. New York: McGraw-Hill Book Company.

Foli EG, Alder D, Miller HG, Swaine MD. 2003. Modelling growing space requirements for some tropical forest tree species. Forest Ecology and Management 173:79-88.

Hemery GE, Savill PS, Pryor SN. 2005. Applications of the crown diameter-stem relationship for different species of broadleaved tress. Forest Ecology and Management 215:285-294. http://dx.doi.org/10.1016/j.foreco. 2005.05 .016

Krishnapillay B. 2000. Silviculture and management of teak plantations. Unasylva 51:14-21.

Laar AV, Akça A. 2007. Forest Mensuration. Berlin: Springer. http://dx.doi.org/10.1007/978-1-4020-5991-9.

Lacret R, Varela RM, Molinillo JMG, Nogueiras C, Macias FA. 2012. Tectonoelins, new norlignans from a bioactive extract of Tectona Grandis. Phytochemistry Letter
5:382-386. http://dx.doi.org/10.1016/j.phytol.2012.03. 008 .

Martawijaya A, Kartasujana I, Danang YIM, Prawira SA, Kadir K. 1989. Atlas Kayu Indonesia. Bogor: Badan Penelitian dan Pengembangan Kehutanan.

Miranda I, Sousa V, Pereira H. 2011. Wood properties of teak (Tectona grandis) from a mature unmanaged stand in East Timor. Journal of Wood Science 57(3):171-178. http://dx.doi.org/10.1007/s10086-010-1164-8.

Perez D, Kanninen M. 2005. Effect of thinning on stem form and wood characteristics of teak (Tectona Grandis) in a humid tropical site in Costa Rica. Silva Fennica 39(2):217-225. http://dx.doi.org/10.14214/sf.385.

Perhutani. 2011. Monitoring dan Evaluasi Pengembangan Jati Plus Perhutani (JPP) di KPH Kendal. Kendal: Perum Perhutani KPH Kendal.

Pretzsch, Schutze. 2005. Crown allometry and growing space efficiency of norway spruce (Picea abies [L.] Karst.) and European Beech (Fagus sylvatica L.) in pure and mixed stands. Plant Biology 7:628-639. http://dx.doi.org/10.1055/s-2005-865965.

Pretzsch H. 2009. Forest Dynamics, Growth and Yield. From Measurement to Model. Berlin Heidelberg: SpringerVerlag. http://dx.doi.org/10.1007/978-3-540-88307-4_1.

Raharjo P. 2009. Impact spacing genetic requirement against genetic tests Shorea leprosula descent, Miq PT Sari Bumi Kusuma, Central Borneo [thesis]. Yogyakarta: Forestry Gadjah Mada University.

Rohman. 2008. Casualty per cent on ACC determination of teak forest plantation in Perum Perhutani. Jurnal Manajemen Hutan Tropika 14(2):54-60.

Rohman, Warsito, Supriyatno, Purwanto, Atmaji. 2014. Evaluation of annual allowable cut (AAC) determination of teak forest plantations in Perum Perhutani, Indonesia. Jurnal Manajemen Hutan Tropika 20(3):195-202. http://dx.doi.org/10.7226/jtfm.20.3.195.

Sadono R, Nirwanawati A, Murdjoko A, Santosa AB, Rachman I. 2014. Growing space estimation of teak through dominant family approach at progeny trial in Ngawi Forest District. Advances in Environmental Biology 8(5):1890-1896.

Sadono R. 2014a. Determining competition level for high genetic value of teak (Tectona grandis L. F) aged 6 to 11 years in Madiun forest district, East Java, Indonesia. Advances in Environmental Biology 8(17):750-756

Sadono R. 2014b. Determining growing space of perhutani's teak plus plantation in Madiun, Saradan dan Ngawi forest district, East Java, Indonesia. Australian Journal of Basic dan Applied Sciences 8(10):427-437. 
Sadono R. 2015. Crown model for Perhutani's teak plus from clonal seed garden aged 6 to 11 years in Madiun Forest District, East Java, Indonesia. Australian Journal of Basic and Applied Sciences 9(5):151-160.

Setyaningsih L, Latupeirissa FM, Supriono B. 2009. Pertumbuhan jati unggul nusantara pada pola tanam tumpangsari di Kebun Percobaan Cogreg. Jurnal Nusa Sylva 9(2):92-97.
Siswamartana S, Wibowo A. 2005. Konservasi genetik jati. In: Siswamartana S, Rosalina U, Wibowo A, editors. Seperempat Abad Pemuliaan Jati. Jakarta: Pusat Pengembangan Sumber Daya Hutan, Perum Perhutani.

Uriarte M, Canham CD, Thompson J, Zimmerman JK. 2004. A neighborhood analysis of tree growth and survival in a hurricane-driven tropical forest. Ecological Monographs 74(4):591-614. http://dx.doi.org/10.1890/03-4031. 